\title{
The 'Hemisphere Isolationists' and Anglo-American Economic Diplomacy during the Second World War
}

Throughout the Second World War a central component of the Franklin D. Roosevelt administration's post-war planning was an attempt to win the support of Great Britain for a multilateral economic system, based on the internationalist principles of free and equal access to the world's markets and resources. This paper explores the impact on Anglo-American economic diplomacy of a faction within the Roosevelt administration, defined as 'hemisphere isolationists'. United by a preoccupation with Latin American affairs, alongside an instinctive disdain for the European powers, this group pursued policies which had the effect of excluding British interests from Latin America for the post-war era. As such, they represented a regionalist challenge to broader internationalist conceptions of the post-war world.

The years following the entry of the United States into the Second World War have often been characterised as witnessing the triumph of internationalism in the country. In this analysis the Japanese attack on Pearl Harbor in December 1941 finally forced the US to abandon its former isolationism, which had shaped the country's foreign policy over the previous decades. In its place the US took the leading role during the war years in the construction of a new world order, based on internationalist principles. The most dramatic expression of this polity came in the US support for an international organisation, based on collective security, to preserve world peace. ${ }^{1}$

Such internationalist principles can also be construed in the Franklin D. Roosevelt administration's advocacy of a multilateral economic system for the post-war world, based on free and equal access for all nations to the world's markets and resources. The chief proponents of this system were a group of economic internationalists in the State Department, led by Secretary of State Cordell Hull. ${ }^{2}$ The motivation behind economic multilateralism, according to this group, went way beyond the realm of commerce. Rather, advocates of 
multilateralsim believed the freer trade achieved by nations would lead to greater prosperity for all. Such prosperity, so the argument went, would eliminate the bases of the economic nationalism that had ultimately led to war. ${ }^{3}$ Economic multilateralism, then, would pave the way for lasting international peace. Understood in this way, the Roosevelt administration's economic ambitions for the post-war world were much more than a single constituent part of a broader internationalist agenda; they were the vital lynchpin upon which an internationalist conception of the post-war world rested.

Key to the attainment of a multilateral economic system was US diplomacy throughout the war with Great Britain. While the threat of the Axis powers had made an ally out of Britain, the country remained the principal commercial rival of the US at the outbreak of the Second World War. Moreover, in response to the Great Depression of the 1930s, Britain had created a protectionist economic system, based on the sterling bloc and the imperial preference system, which discriminated against outside powers. ${ }^{4}$ Such a regime stood in stark contrast to the multilateral system sought by the Roosevelt administration's internationalists. It was therefore to the task of breaking open Britain's closed trade system and replacing it with its own multilateral model that the Roosevelt administration applied itself in negotiations with its wartime ally. The British government resisted this attempt for fear that the loss of export markets provided by Britain's closed trading system would deny the country the means of achieving a healthy balance of payments in the post-war era. But British dependence on the US for aid meant that concessions with regard to post-war economic planning were inevitable.

This process began in August 1941 when point four of the Atlantic Charter declared that the US and Britain would endeavour to ensure future equal access, for all countries, 'to trade and to the raw materials of the world which are needed for their economic prosperity'. The Master Lend-Lease Agreement, signed the following February, further pledged that the US and Britain would work toward 'the elimination of all forms of discriminatory treatment in international commerce, and to the reduction of tariffs and other barriers to trade' ${ }^{6}$ In the 
years following this agreement US officials sought to implement its provisions to ensure future US access to the British Empire and the sterling bloc. ${ }^{7}$ Similarly, US officials sought to challenge Britain's traditional dominance in the Middle East in order to facilitate future US commercial penetration - again in the name of promoting multilateralism. ${ }^{8}$ These efforts were furthered during the principal wartime international conference on economic matters, held at Bretton Woods in July 1944. The final text of the agreements reached at the conference recorded the US desire 'to bring about further agreement and cooperation among nations ... on ways and means which will best reduce obstacles to and restrictions upon international trade'. ${ }^{9}$ This process reached a conclusion with the Anglo-American financial agreement of December 1946, which granted Britain a loan to aid reconstruction on the condition that it be used 'to assume the obligations of multilateral trade'. ${ }^{10}$ Thus, there was a consistent pattern throughout the Second World War - both in general negotiations and at the regional level - whereby the Roosevelt administration sought to ensure British acceptance of a multilateral economic system for the post-war world.

The argument advanced in this paper is that US policy toward Britain in Latin America failed to conform to this pattern. Internationalist forces were certainly present in the formulation of US policy in this region. However, these were counteracted throughout the war years by a faction within the Roosevelt administration defined here as 'Hemisphere isolationists'. ${ }^{11}$ This loose coalition was formed of various sections of the US governmental bureaucracy, the most important of which was the Latin Americanists in the State Department. Led by Under Secretary of State Sumner Welles, this group also included Laurence Duggan, Assistant Secretary for Political Affairs, and members of the Division of American Republic Affairs. Imbued with an in-depth knowledge of Latin America and a sensitivity toward the politics of the region, this group were at the forefront of guiding US Latin American policy during the Second World War. ${ }^{12}$ Alongside the State Department's Latin Americanists, temporary government agencies, set up for specific wartime purposes, also played an important role in implementing US policy in Latin America. These agencies 
often worked in close alliance with - and were indeed often represented by - US business interests with long-standing commercial ties to Latin America, as well as ambitions to extend such interests in the future.

The Hemisphere isolationists were thus a diverse group with differing ambitions and separate bureaucratic functions. What they had in common was a preoccupation throughout the war years on Latin America, which dovetailed with a general scepticism toward Europe, ranging from aloof disinterest to open hostility. ${ }^{13}$ In this sense, the isolationism of this group was based not so much on opposition to US involvement in European affairs; the majority supported US intervention in the war and future participation in an international organisation. ${ }^{14}$ But when it came to continued European involvement in the affairs of Latin America, this group was instinctively hostile to such a prospect. This parochial, hemispheric world-view, while not necessarily directed specifically at Britain, led the Hemisphere isolationists to pursue policies which often threatened to exclude British interests from Latin America for the post-war years.

Such a goal clearly stood in stark contradiction to the efforts of the economic internationalists to win British support for a global system in the post-war era based on free and equal access to the world's markets and resources. Moreover, with the system of economic multilateralism viewed - as indeed it was by its advocates - as essential to the broader internationalist conception of a post-war world, the challenge to this system by Hemisphere internationalists in Latin America posed a severe threat to the triumph of internationalism during the Second World War.

So while Hemisphere isolationists may not have been 'traditional' isolationists, their aversion to British interests in Latin America certainly did contradict internationalist conceptions of the post-war world. By highlighting this regional challenge to internationalism this paper seeks to demonstrate that variations of isolationist sentiment did indeed continue to find expression in the years after the US entered the Second World War. By exploring the impact that this faction had on Anglo-American economic diplomacy during the Second 
World War, this paper will therefore contribute towards a more nuanced understanding of the ideological forces shaping transatlantic relations in these years.

\section{Sumner Welles and the Inter-American System}

British interests in Latin America by the time of the Second World War, while much diminished since the country's former dominance of the region in the nineteenth century, were still significant. On the eve of war in 1938 Britain supplied 12 percent of the region's imports and received 17 percent of its exports. ${ }^{15}$ Moreover, Britain was the principal customer for important South American exports like Argentine meat and Bolivian tin, and retained significant investment in countries like Brazil and Venezuela. ${ }^{16}$ Following Pearl Harbor and the subsequent US entry into the war, there was a general consensus among British officials that the surest means of protecting these interests was to foster a spirit of collaboration with the US in the region, which would entail an active role for Britain.

Consequently, in a meeting between Lord Halifax, the British ambassador in Washington, and Sumner Welles on 28 December the former expressed Britain's desire to play a constructive role in the affairs of Latin America. But Welles' response was vague and noncommittal, giving only a brief outline of current US goals in the region that seemingly contained no place for Britain. ${ }^{17}$ Such an attitude on Welles' part toward British interests in Latin America was reaffirmed during the first inter-American conference since the US entered the war, held in Rio de Janeiro during the second half of January 1942. During the conference British hopes of having any input on the proceedings were dashed when Welles, who headed the US delegation, failed to find the time to receive Sir Noel Charles, the British ambassador in Rio. $^{18}$

These early indications of Welles' attitude toward British interests in Latin America were confirmed throughout his tenure as Under Secretary. Moreover, by the time of the Second World War, Welles led a powerful group of Latin Americanists within the State Department who shared his views toward the region and worked toward their realization. As 
such, the contradictions that existed in Welles' own thinking about Latin America and postwar economic planning reflected the broader divergence between Latin Americanists and internationalists within the State Department.

Welles advocated a global system of economic multilateralism for the post-war world in a similar vein to Cordell Hull and other internationalists. Indeed, Welles had played a significant role in attempting to win British support for a commitment to multilateralism in the Atlantic Charter declaration of 1941. As he recalled in his memoirs, his goal during these negotiations was to ensure that the US and Britain "jointly assume leadership in the post-war world in bringing about the elimination of autarchic trade systems, and in abolishing ... discriminatory commercial arrangements'. ${ }^{19}$ But while Welles was certainly involved in postwar planning with the British during the war, his principal focus was on Latin American policy.

Welles had long been an authority on Latin American affairs. He first gained experience of the region while serving as commercial attaché in Buenos Aires during the First World War and later as Chief of the Division of Latin American Affairs in the early 1920s. By the time Roosevelt came to power in 1933 Welles had developed a sophisticated understanding of the politics of the region, as well as fluency in Spanish. ${ }^{20}$ This expertise in Latin American affairs, alongside his friendship with Roosevelt, made Welles an obvious choice to serve as Assistant Secretary of State for Latin American Affairs in the new administration. ${ }^{21}$ In this role, during his brief interregnum as ambassador to Cuba, and finally as Under Secretary of State, Welles became the dominant figure throughout the 1930s implementing the administration's Good Neighbour Policy toward Latin America. ${ }^{22}$ Throughout this period Welles' overriding aim was to forge an inter-American system, based on the principle of judicial equality between states. ${ }^{23}$

As the threat of war in Europe loomed, the primary concern of US policy in Latin America - with Welles as the chief protagonist - was to engender sufficient unity among the American states to ensure the security of the Western Hemisphere. ${ }^{24}$ Substantial progress 
toward this goal was made at the Buenos Aires conference in 1936 where the principle was established that a threat to any American state was a threat to all. ${ }^{25}$ Welles was subsequently successful in maintaining a degree of unity among the American states at the Rio conference of 1942 when all agreed to a resolution advocating the breaking of relations with the Axis countries, following the attack on Pearl Harbor. ${ }^{26}$ As Welles looked to the post-war era, maintaining the unity forged among the American states throughout the war - and therefore the integrity of the inter-American system - became one of his principal priorities.

In common with most other US officials Welles believed that the inter-American system should serve as a model for the rest of the world to replicate in the post-war era. ${ }^{27}$ However, while this was certainly a valid aspiration for Welles, his opinion of Europe made it seem an unlikely outcome. Welles viewed the major European countries of the 1930s - be they Axis or Allied - as unreformed imperialist powers. ${ }^{28}$ He therefore held out little hope of them replicating the kind of respect for sovereign equality among states, which he believed to have been established in the Western Hemisphere. Welles subsequently held fast to the belief throughout the war that 'the cornerstone of [US] foreign policy' in the post-war era should be continued participation in the inter-American system. ${ }^{29}$

\section{An 'Economic Monroe Doctrine'}

Welles' dim view of the European powers, combined with his desire to preserve the integrity of the Inter-American system, led to a natural aversion to European influence and interests in Latin America as he looked toward the post-war years. Echoing the Monroe Doctrine, first pronounced in the nineteenth century, Welles was concerned that European powers would use their influence in a particular Latin American state in order to disrupt the unity of the inter-American system. Welles was well aware that no European power was likely to achieve sufficient overt political control over any Latin American country in the post-war era to threaten the security of the Western Hemisphere. However, throughout the war he came to the belief that economic domination of a Latin American country by a single European power 
necessarily implied a threatening degree of undue political influence, which could, by extension, threaten hemispheric security. He subsequently formulated a post-war aim of eradicating European economic domination of any one Latin American country. ${ }^{30}$

During the winter of 1942-1943 it became clear to British officials that this ambition on Welles' part applied equally to Britain as to a resurgent Germany or Italy. During an informal conversation between Welles and Kenneth Grubb, a prominent official in the Ministry of Information with substantial experience of Latin America, the latter pushed Welles for his post-war policy toward Latin America. ${ }^{31}$ Welles sought to reassure Grubb that 'he was wrongly interpreted if it was supposed that he intended to make Latin America what was loosely called "an exclusive economic preserve for North American interests"'. Nor was he 'disposed to quarrel with the rights of free enterprise in its usual form'. However, he went on to express his fear that 'the countries of Europe would after the war tend to build up their commerce in the form of virtually state controlled corporations'. 'Such corporations in the field of foreign trade', Welles continued, 'necessarily exercised a penetrative political influence, although they did so under the guise of free competition and economic assistance'. In order to meet the threat of European powers using a position of commercial dominance to disrupt the political unity of the Western Hemisphere, it was therefore necessary, Welles believed, for the US 'to build up a position both in the political and economic fields which would enable them to occlude any such ... activities' ${ }^{32}$

Welles justified his aversion to significant European economic interests in Latin America on the basis of preserving the political stability of the Western Hemisphere, and by extension the US security. This concern was no doubt genuine and was indeed greeted sympathetically by some in the British government. ${ }^{33}$ But regardless of the rationalisation offered by Welles for his policy toward Latin America, what remained explicit was that such as policy would necessarily require US commercial dominance of the region, to the exclusion of significant British interests. To that extent, the attitude espoused by Welles toward Latin 
America failed to chime with the Roosevelt administration's internationalist policy of economic multilateralism.

While Welles was clearly influential in the formulation of US policy in Latin America, his was not the only voice in the State Department. Anglophile internationalists like Assistant Secretary of State Dean Acheson periodically sought to ensure that the principle of free and equal access to trade and resources did indeed apply to Britain in Latin America. In July 1942, for example, Acheson sent a memo to all US representatives in Latin America emphasising the universal application of economic multilateralism and advocating a 'a liveand-let-live policy' with regard to British interests in the region. ${ }^{34}$ But the existence of these contradictory trends within the State Department meant that it was not possible for multilateralism to be advocated in a clear and consistent manner in the department's diplomacy with Britain concerning Latin America.

Although Welles had been the chief advocate of an economic Monroe Doctrine, the essentials of this conception of US security - albeit in a less extreme form - remained after his departure from office in September 1943. Specifically, while the US would not oppose economic penetration of Latin America by European powers per se, economic interests that took on a political dimension would continue to be viewed as a threat to US security in the post-war era, and would not, therefore, be tolerated.

This view was made clear to Rodney Gallop, assistant to the head of the Foreign Office's South American department, when he visited Washington in February 1944. In a meeting with Berle it was explained that the US interest in Latin America was 'primarily strategic'. As a result of this concern, Berle stated, 'the United States could not allow an outside Power to establish a bridgehead there. Britain', Berle stressed, 'was neither explicitly excluded nor included in this formula' ${ }^{35}$ Similarly, in an evaluation of the State Department's attitude following Welles' departure, the British embassy in Washington reported that while 'trade exchange' between 'non-American countries' and Latin America would not be opposed by the US, this would only be permissible, "provided always that such 
exchange does not offer a danger to the security of the American hemisphere by assuming a political complexion'.36

Welles' effective replacement as the leader of Latin America policy in the State Department came in the form of Nelson A. Rockefeller's appointment to the newly created post of Assistant Secretary of State for American Republic Affairs in December 1944. Rockefeller's appointment also represented a continuity of Welles' thought when it came to Latin American affairs. Indeed, Rockefeller had demonstrated an exclusivist attitude toward the region throughout the war while heading one of the most influential temporary agencies operating in the region.

\section{Nelson Rockefeller and CIAA}

As a life-long Republican and a firm believer in the primacy of private enterprise and limited government, Rockefeller was an unlikely member of the Roosevelt administration. ${ }^{37}$ However, his experience of Latin America gained through business investments in Venezuela, along with his youthful enthusiasm, impressed Roosevelt. In August 1940 the President consequently appointed Rockefeller head of a newly created agency to deal solely with issues relating to the Western Hemisphere. ${ }^{38}$ The new agency's functions were initially limited to strengthening cultural ties and engendering goodwill between the American republics, as well unofficial action aimed at eradicating Nazi influences from the region. ${ }^{39}$

However, in July 1941, following a change of name to the Office for the Coordinator of Inter-American Affairs (CIAA) the agency took on far greater responsibilities. ${ }^{40}$ These included promoting US-Latin American trade and the development of Latin American economies with US capital. ${ }^{41}$ There were certainly wartime justifications for these functions. Increased US trade with Latin America could compensate for the loss of the region's traditional European trading partners and thereby forestall any social unrest that could threaten inter-American security. Similarly, the development of Latin American industry 
could create goodwill for the US, as well as more tangible result like facilities that would serve strategic purposes. ${ }^{42}$

But the growing prominence of Rockefeller's agency in the economic affairs of Latin America had potential implications regarding the post-war era and was therefore a source of consternation to British observers. In December 1942 Halifax informed the Foreign Office of his concerns over Rockefeller's organisation, noting that while it had been created as a temporary wartime agency, its increasing functions gave the impression 'that it is being built up with an idea of permanency'. Moreover, the economic policies of Rockefeller's agency, Halifax went on, 'are bound to have very wide repercussions on the future economy of Latin America as well as ... the relations of these countries with the rest of the world' ${ }^{43}$

British fears over the role of CIAA were seemingly realised when officials in London became aware in late 1942 that Rockefeller had secured a pledge from the US Treasury ensuring that advertising costs incurred by US business in Latin America would be deductible for federal income tax purposes. ${ }^{44}$ This governmental support for US advertising in Latin America struck a particular chord among British officials, as they had been actively restraining British firms from carrying out such promotional activities, both in order to preserve scarce resources and to avoid inviting criticism from the US. ${ }^{45}$ The failure on the part of the US government to mirror such restraint was later justified to British officials in Washington on the grounds that it was only by way of US advertising revenue that friendly newspapers in Latin America could stay in business throughout the war and continue to propagate pro-Allied stories. ${ }^{46}$ This reasoning was not without merit, and it was certainly one of the motivations that had driven Rockefeller in advocating the increase in US advertising in Latin America. $^{47}$

But in making the case to US business to maintain their advertising in the region throughout the war, Rockefeller was clear that this action would serve post-war purposes as well. Writing to five hundred export firms in the summer of 1942, Rockefeller stated that 'there is great need right now for foresighted planning and courageous effort by U.S. industry 
to hold for the future its well earned position in the economic life of our neighbouring markets'. ${ }^{48}$ Writing in a US trade journal in August 1942, Rockefeller's assistant, Joseph C. Rovensky, was even more explicit about the post-war aspect of wartime advertising in Latin America. Rockefeller's advertising plan, stated Rovensky, is 'a dual purpose project - it is both part of the nation's war effort and a plan for enabling [US] exporters to maintain their trade positions in Latin America, now and after the war'. The plan, Rovensky continued, 'has been conceived and is being implemented by realistic Government officials and businessmen, who are thinking realistically in terms of to-day and after the war' ${ }^{49}$

From Britain's perspective, the promotion of US post-war trade prospects in Latin America, while British advertisers were being restrained from similar activities, represented a threat to British interests in the region. However, while Rockefeller was clearly keen to promote US trade in Latin America, his attitude toward European interests in the region was more one of disinterest than of active opposition. Of much greater concern to British officials were comments made by Eric Johnston.

\section{Eric Johnston and 'Vertical Trade'}

As both head of the US Chamber of Commerce and Chairman of the US Committee of the Inter-American Development Commission (IADC), Johnston had clear links both to US business and official Washington. ${ }^{50}$ Although a Republican and president of a body that had traditionally been hostile toward the New Deal, Johnston forged a close relationship with Roosevelt and gained a prominent role in the direction of Latin American affairs during the war. ${ }^{51}$ In March 1943 Johnston toured Latin America to meet with officials and businessmen and discuss US-Latin American trade in the post-war era. ${ }^{52}$ On completion of his trip Johnston gave several press conferences where he outlined his thinking on Latin American trade in the post-war period. In his remarks Johnston endorsed the multilateral trade programme, insofar as he advocated a decrease in barriers to trade between the US and Latin America. But he also predicted that post-war trade would tend to flow along 'vertical lines', 
with the US conducting the baulk of its commerce with Latin America and European trade being focussed on Africa. Whereas international commerce had 'heretofore ... been mainly an east to west affair', in the post-war world Johnston believed that 'there must be an increase in north to south development, ... particularly in the Western Hemisphere ${ }^{53}$ Just as the last century in Latin America was a 'British Century', stated Johnston, the next would be an American Century. ${ }^{54}$

A few days later, Johnston met with Roosevelt to discuss his plans for the development of post-war trade in Latin America. In his subsequent report to the press on the meeting Johnston once again reiterated his belief in the need to remove barriers to trade in Latin America. However, as previously, Johnston's comments also indicated that this increase in trade would only apply within the Western Hemisphere. The development of Latin America, stated Johnston, would be carried out by US and Latin American interests 'on a fifty-fifty basis, 55

As with his earlier remarks, this picture of post-war trade in Latin America seemed to hold little place for Britain. Sir Noel Charles gave his reaction to Johnston's remarks in a telegram that was circulated among the War Cabinet in London. While the Roosevelt administration may officially advocate economic multilateralism in negotiations with Britain, it was comments like Johnston's, believed Charles, which revealed the true ambitions of the US in Latin America. ${ }^{56}$ Similarly, Gallop noted with disapproval the failure of the State Department to disavow Johnston's comments regarding the future pattern of international trade, despite the apparent contradiction between his views and the official US policy of multilateralism. ${ }^{57}$

\section{Conclusion}

The contradiction between the type of hemispheric isolationism expressed by Johnston and the multilateral trade programme advocated by internationalists in the State Department was never reconciled. As such, there remained throughout the war years, a faction within the 
Roosevelt administration that hoped, for a number of reasons, to isolate the Western

Hemisphere from external influence on a permanent basis. While the exclusion of British interests may by no means have been the primary aim of this desire, it was certainly a wholly foreseeable consequence. When viewed in the broader context of the Roosevelt administration's attempts to promote an economic system for the post-war world based on free and equal access, the implications of excluding British interests from Latin America are worth drawing attention to.

Protection of British export markets in Latin America was deemed by the British government to be an essential prerequisite of the country effectively participating in the kind of multilateral system that the US advocated for the post-war world. For if these markets were not retained for the post-war era, British officials believed, such a system would not provide the country the means to ensure a favourable balance of payments, essential for Britain's prosperity. When Britain did embark on a post-war export drive its markets in Latin America had indeed in large part been lost to US competition. By 1947 US exports dominated throughout Latin America. In Brazil US exports constituted 61 percent of the country's total imports, compared to just 7 percent supplied by Britain. In Argentina, the onetime stronghold of British interests in Latin America, the US now supplied just under half of the country's imports, whereas Britain supplied only 8 percent. ${ }^{58}$ While it is impossible to state to what extent the policies of the Hemisphere isolationists directly contributed to the loss of British influence in Latin America, their presence was certainly a significant factor. Albeit as part of a much broader process, this loss of export markets in Latin America - as predicted by British officials during the war - seriously hindered the country's ability to participate in a global multilateral system in the post-war era. ${ }^{59}$

Perhaps of greater long-term significance are the geopolitical ramifications of the Roosevelt administration's failure to promote multilateralism effectively in Latin America. Economic multilateralism was, by its very nature, a global system. As such, any regional exceptions from this system could not be accommodated. To the contrary, the theory of 
economic multilateralism stated that is was precisely the creation of closed economic spheres that eventually led to international conflict. As one US supporter of multilateralism predicted in 1943, 'where policies give exclusive privileges to [Western] hemisphere nations, retaliatory measures by other economic blocs such as the British Empire ... may well develop'. ${ }^{60}$ It was, of course, not Britain but the Soviet Union that turned out to be the principal rival that the US faced in the post-war era. To explore the effects of the US attitude toward Latin America on Soviet-American relations would take this paper beyond its natural limits. ${ }^{61}$ It is, however, perhaps worth pointing to the remarks of the US Deputy Director of Naval Intelligence, who reported in January 1946 that "Soviet current policy is to establish a Soviet Monroe Doctrine for the area under her shadow". ${ }^{62}$ Again, while it is impossible to measure precisely the impact of the Hemisphere isolationists on the actions of other countries, this group's retention of an exclusivist attitude toward Latin America was surely a hindrance in the Roosevelt administration's promotion of internationalism when looking toward the post-war world.

\footnotetext{
${ }^{1}$ The most prominent example of this thesis is Robert A. Divine, Second Chance: The Triumph of Internationalism in America during World War II (New York, Atheneum, 1967). For more recent examples, see Tony Smith, America's Mission: The United States and the Worldwide Struggle for Democracy in the Twentieth Century (Princeton New Jersey, Princeton University Press, 1994), 113-145; Frank Ninkovich, The Wilsonian Century: US Foreign Policy since 1900 (Chicago Illinois, University of Chicago Press, 1999), 137-144.

${ }^{2}$ For more on economic internationalists in the State Department, see Richard Gardner, Sterling-Dollar Diplomacy: Anglo-American Collaboration in the Reconstruction of Multilateral Trade (Oxford, Clarendon Press, 1956), 16; Randall B. Woods, A Changing of the Guard (Chapel Hill North Carolina, University of North Carolina Press, 1990), 13; Donald Cameron Watt, Succeeding John Bull: America in Britain's Place, 19001975: A Study of the Anglo-American Relationship and World Politics in the Context of British and American Foreign-Policy-making in the Twentieth Century (Cambridge, Cambridge University Press, 1984), 95.

${ }^{3}$ Cordell Hull, The Memoirs of Cordell Hull, 2 vols (New York, Macmillan, 1948), vol. 1, 81-86, 363-365. For further examples of this thesis by officials who participated in wartime diplomacy, see Herbert Feis, The Sinews of Peace (New York, Harper \& Bothers, 1944), ch.3; E. F. Penrose, Economic Planning for Peace (Princeton New Jersey, Princeton University Press, 1953), ch.1.
} 
${ }^{4}$ Frederick Benham, Great Britain Under Protection (New York, Macmillan, 1941), 90-102.

${ }^{5}$ Foreign Relations of the United States [FRUS], 1941, vol. 1 (Washington DC, USGPO, 1958), 367-369. For

Anglo-American negotiations concerning point four of the charter, see FRUS, 1941, vol. 1, 360-373.

${ }^{6}$ Department of State Bulletin, 28 Feb. 1942 (Washington DC, USGPO, 1942). For the negotiations leading to the Master Lend-Lease Agreement, see FRUS, 1942, vol. 1, 525-537.

${ }^{7}$ Harley A. Notter, Post-War Foreign Policy Preparation (Washington DC, USGPO, 1949), 190-194.

${ }^{8}$ Lloyd C. Gardner, Economic Aspects of New Deal Diplomacy, $2^{\text {nd }}$ edition (Boston Massachusetts, Beacon Press, 1971), 217-236; Gabriel Kolko, The Politics of War: Allied Diplomacy and the Crisis of 1943-1945 (London, Weidenfeld \& Nicolson, 1968), 294-313.

9 'Proceedings and Documents of the United Nations Monetary and Financial Conference, Bretton Woods, New Hampshire, July 1-22, 1944', Department of State Publication 2866 (Washington DC, USGPO, 1948).

10 'Financial Agreement Between the Governments of the United States and the United Kingdom', Department of State Publication 2439 (Washington DC, USGPO, 1946), 7. For the negotiations leading to the financial agreement, see FRUS, 1945, vol. 6, 1-204.

${ }^{11}$ References to this term, or variations of it, can be found in the following primary and secondary sources: Report by Humphreys for Bonham-Carter, undated [Feb. 1942], Foreign Office General Correspondence, FO371/33908/A3996 [hereafter cited as FO371 with file numbers], The National Archives of the United Kingdom, Kew, London [hereafter TNA]; Washington to Foreign Office, 29 Apr. 1943, FO371/33908/A3996, TNA; Watt, Succeeding John Bull, 91.

${ }^{12}$ For more on Latin Americanists in the State Department, see Randall B. Woods, The Roosevelt Foreign Policy Establishment and the 'Good Neighbor': The United States and Argentina, 1941-1945 (Lawrence Kansas, Regents Press, 1979), 23-24.

${ }^{13}$ John Harper has characterised this attitude within the Roosevelt administration as 'Europhobichemispherism'. See John Harper, American Visions of Europe: Franklin D. Roosevelt, George F. Kennan, and Dean G. Acheson (Cambridge, Cambridge University Press, 1994), 60.

${ }^{14}$ For example, Welles confirmed his support for an international organisation in a Memorial Day speech in 1942. See Divine, Second Chance, 66.

${ }^{15}$ Raul C. Migone ed., Inter-American Statistical Yearbook, 1940 (New York, Macmillan, 1940), 158-161.

${ }^{16}$ Rory Miller, Britain and Latin America in the Nineteenth and Twentieth Centuries (London, Longman, 1993), 151-152; 'British Investments in Latin America', South American Journal, 14 Jan. 1939, 26; Migone ed., InterAmerican Statistical Yearbook, 1940, 158-161.

${ }^{17}$ Washington to FO, 27 Dec. 1941, FO371/26036/A10669, TNA. 
${ }^{18}$ Draft memo by Gallop, FO371/30503/A1817, TNA; 'Memorandum respecting the Anglo-United States-

Brazilian Triangle' by Gallop, 15 Jul. 1942, FO371/30369/A6565, TNA.

${ }^{19}$ Sumner Welles, The Time for Decision (London, Hamish Hamilton, 1944), 140.

${ }^{20}$ Benjamin Welles, Sumner Welles: FDR's Global Strategist (Basingstoke, Macmillan, 1997), 52-79; Harper, American Visions of Europe, 56.

${ }^{21}$ Welles, Sumner Welles, 134-155; Harper, American Visions of Europe, 56.

${ }^{22}$ Welles, Sumner Welles, 156-208; Welles, The Time for Decision, 145-188; Laurence Duggan, The Americas:

The Search for Hemisphere Security (New York, Henry Holt and Company, 1949), 102-103.

23 'Welles to Roosevelt: A Memorandum on Inter-American Relations, 1933', OF470, Franklin D. Roosevelt

Papers, Hyde Park New York [hereafter FDR Papers]; Woods, The Roosevelt Foreign Policy Establishment and the 'Good Neighbor', 23; Welles, The Time for Decision, 145, 150, 186.

${ }^{24}$ Ibid., 160; Duggan, The Americas, 70-72.

${ }^{25}$ Welles, The Time for Decision, 161-163.

${ }^{26}$ Ibid., 175-184. See also Michael J. Francis, 'The United States at Rio, 1941: The Strains of PanAmericanism', Journal of Latin American Studies, 6, no. 1 (1974), 77-95; Woods, The Roosevelt Foreign Policy Establishment and the 'Good Neighbour', 27-42.

${ }^{27}$ For reference to this widely held belief, see 'The Pan American Union in the Post-War World' memo by Halle, 1 Feb 1943, Memorandums Relating to General Latin America Affairs, Office of American Republic Affairs, Box 8, Record Group 59 [hereafter RG59], United States National Archives and Records Administration, College Park Maryland [hereafter NARA]; 'Speech of Mr. Henry A. Wallace at a Rally Celebrating “I am an American Day”, 16 May 1943, FO371/33901/A4771, TNA; Hull, The Memoirs of Cordell Hull, vol. 1, 309, 320-321, 344, 349-350; Warren F. Kimball, The Juggler: Franklin Roosevelt as Wartime Statesman (Princeton New Jersey, Princeton University Press, 1991), 107-125.

${ }^{28}$ Harper, American Visions of Europe, 56-57.

${ }^{29}$ Welles, The Time for Decision, 187.

${ }^{30}$ Grubb to Perowne, 21 Jan. 1943, FO371/33903/A959, TNA.

${ }^{31}$ For more on Grubb, see Kenneth Grubb, Crypts of Power (London, Hodder \& Stoughton, 1971).

${ }^{32}$ Grubb to Perowne, 21 Jan. 1943, FO371/33903/A959, TNA.

${ }^{33}$ See, for example, Campbell to Perowne, 29 May 1943, FO371/33903/A5359, TNA.

${ }^{34}$ Acheson to American Diplomatic and Consular Offices in the other American Republics, 10 Jul. 1942, State

Department Decimal File, 610.4117/30A [hereafter cited by decimal reference], RG59, NARA.

35 'Notes on a Visit to Washington and Ottawa' by Gallop, 14 Mar. 1944, FO371/35185/AS1621, TNA. 
${ }^{36}$ Campbell to Eden, 3 Nov. 1943, FO371/33902/A10016, TNA. See also Gainer to Eden, 30 Nov. 1943, FO371/33902/A10863, TNA.

${ }^{37}$ James Desmond, Nelson Rockefeller: A Political Biography (New York, Macmillan, 1964), 79-80, 102.

38 'Order Establishing the Office, August 16, 1940’, Leland M. Goodrich ed., Documents on American Foreign Relations, vol. 3, July 1940-June 1941 (Boston Massachusetts, World Peace Foundation, 1942), 109-110. For more on Rockefeller's background in Latin American affairs, see Desmond, Nelson Rockefeller, 52-64. For Rockefeller's relationship with Roosevelt, see Desmond, Nelson Rockefeller, 73, 89.

39 'Executive Order No.8840 Establishing the Office of the Coordinator of Inter-American Affairs in the Executive office of the President and Defining its Functions and Duties, July 30, 1941', Goodrich ed., Documents on American Foreign Relations, Vol. 4, July 1941-June 1942, 329-332; Halifax to Eden, 29 Dec. 1942, FO371/30508/A12038, TNA; Paul Kramer, 'Nelson Rockefeller and British Security Coordination', Journal of Contemporary History, 16, no. 1 (1981), 76-77.

${ }^{40}$ Rockefeller to Roosevelt, 27 Aug. 1941, OF412, Box 1, FDR Papers.

${ }^{41}$ Halifax to Eden, 29 Dec. 1942, FO371/30508/A12038, TNA. Indicative of the increasing status of the agency is the increase in its budget. Initially allocated funding of $\$ 3.5$ million, by 1942 CIAA was in receipt of $\$ 38$ million. See Gerald K. Haines, 'Under the Eagle's Wing: The Franklin Roosevelt Administration Forges an American Hemisphere', Diplomatic History, 4, no. 1 (1977), 380.

${ }^{42}$ Desmond, Nelson Rockefeller, 92; Gordon Connell-Smith, The Inter-American System (London, Oxford University Press, 1966), 119; David Green, The Containment of Latin America: A History of the Myths and Realities of the Good Neighbor Policy (Chicago Illinois, Quadrangle Books, 1971), 48-49.

${ }^{43}$ Halifax to Eden, 29 Dec. 1942, FO371/30508/A12038, TNA. Similar concerns were heard from British officials throughout Latin America. See, for example, Blair to Sands, 18 Nov. 1942, FO371/30516/A10802, TNA; Bonham-Carter to Perowne, 25 Jan. 1942, FO371/33901/A281, TNA.

${ }^{44}$ Davidson to Dalton, 11 Nov. 1942, Sullivan to Rockefeller, 17 Jul. 1942, FO371/30516/A11310, TNA; 'Extract from letter of July, 1942, from the Treasury Department to Nelson Rockefeller', FO371/33901/A3135, TNA; 'Internal Revenue Code', 1942, Trade Promotion, Box 31, Subject File, Records of the Office of the Administrator, Records of the Foreign Economic Administration, RG169, NARA.

${ }^{45}$ Davidson to Dalton, 11 Nov. 1942, FO371/30516/A11310, TNA.

${ }^{46}$ Halifax to MOI, 3 Mar. 1943, FO371/33907/A2308, TNA; Campbell to Kelly, 22 Apr. 1943, FO371/33908/A3958, TNA.

${ }^{47}$ Desmond, Nelson Rockefeller, 97. 
48 'The Coordinator Writes to 500 Exporters', Export Trade and Shipper, July 1942, 6. See also Rockefeller's remarks to the Economic Club of New York in April 1943. 'Opportunity Seen in South America', New York Times, 2 Apr. 1943, 10.

49 'How the Rockefeller Plan is Being Implemented', 17 Aug. 1942, Export Trade and Shipper, 5-8. For more on US advertising during the war, see 'Advertising in the War', Time, 22 Mar. 1943, available at: http://www.time.com/time/magazine/article/0,9171,796133,00.html (accessed 17 May 2009).

${ }^{50}$ The Inter-American Development Commission was established by the Inter-American Financial and Economic Advisory Committee following the meeting of the Ministers of Foreign Affairs of the American Republics in Panama in September 1939.

${ }^{51}$ For more on Johnston, see 'Surprise for Mr. Roosevelt', Time, 19 Jun 1942, available at: http://www.time.com/time/magazine/article/0,9171,795956,00.html (accessed 2 Feb. 2009).

52 'Johnston in Panama, Optimistic on Tour', New York Times, 26 Mar. 1943, 8; 'New Ambassador', Time, 15 Mar. 1943, available at: http://www.time.com/time/magazine/article/0,9171,884816,00.html (accessed 2 Feb. 2009).

${ }^{53}$ Johnston in Panama, Optimistic on Tour', New York Times, 26 Mar. 1943, 8; Rio to Foreign Office, 23 Mar. 1943, FO371/33666/A3348, TNA.

54 'President of US Chamber of Commerce on "American Century",', 26 June 1943, South American Journal, 338; 'The Future of Investment in Latin America', 11 Mar. 1944, South American Journal, 150.

55 'See the President on Americas Plan', New York Times, 22 Mar. 1943, 14; 'Business Opportunities in South America', Buenos Aries Herald, 22 Mar. 1943, Hadow to Perowne, 22 Mar. 1943, FO371/33907/A3491, TNA. ${ }^{56}$ Rio to Foreign Office, 23 Mar. 1943, FO371/33666/A3348, TNA.

${ }^{57}$ Gallop minute, 27 Apr. 1943, FO371/33908/A3834, TNA. For further concern among British officials following Johnston's remarks, see Buenos Aires to FO, 2 Apr. 1943, FO371/33907/A3215, TNA; Snow to Eden, 24 Mar. 1943, Perowne minute, 15 Apr. 1943, FO371/33812/A3341, TNA.

${ }^{58}$ Wendell C. Gordon, The Economy of Latin America (New York, Colombia University Press, 1950), 389.

${ }^{59}$ For the more general process whereby the US supplanted Britain as the leading commercial power in the world during the course of the twentieth century, see Paul Kennedy, The Rise and Fall of Great Powers: Economic Change and Military Conflict from 1500 to 2000 (London, Fontana Press, 1988), 459-473.

${ }^{60}$ A. C. Bunce, 'The Hemisphere and the Postwar World' (Washington DC, The National Policy Committee, 1943), Folder 8, Box 102, Jacob Viner Papers, Seeley G. Mudd Manuscript Library, Princeton University, Princeton New Jersey. 
${ }^{61}$ For more on this topic, see Walter LaFeber, America, Russia and the Cold War, 1945-1992 (New York, McGraw-Hill, 1993), 22-23; Barton J. Bernstein, ‘American Foreign Policy and the Origins of the Cold War' in Barton J. Bernstein ed., The Politics and Policies of the Truman Administration (Chicago Illinois, Quadrangle Books, 1970), 40-41; Green, The Containment of Latin America, 217-230; Kolko, The Politics of War, 458-465, 469-475.

${ }^{62}$ Quoted in Bernstein, 'American Foreign Policy and the Origins of the Cold War', 40. 